\title{
Effect of Principal Managerial Leadership and Compensation towards Physics Teacher Performance in Senior High School in Baguala District-Ambon
}

\author{
Izaak Hendrik Wenno ${ }^{1}$ \\ ${ }^{1}$ Physics Education Program, Faculty of Teaching and Education, Pattimura University, Ambon-Maluku, \\ Indonesia \\ Correspondence: Izaak Hendrik Wenno, Physics Education Program, Faculty of Teaching and Education, \\ Pattimura University, Ambon-Maluku, Indonesia. E-mail: wennoiz@yahoo.co.id
}

Received: May 30, 2016

doi:10.5539/ies.v10n1p233
Accepted: July 1, $2016 \quad$ Online Published: December 26, 2016

URL: http://dx.doi.org/10.5539/ies.v10n1p233

\begin{abstract}
The performance of teachers is an important factor that must be considered in efforts to improve the quality of education. Teacher's performance is affected by many factors. Factors that affect the performance of teachers are principals' managerial leadership and compensation. The purpose of this study was to determine the effect of principals' managerial leadership and compensation to the performance of physical science teachers in senior high schools in the district Baguala Ambon city. This type of research is quantitative design. The instrument was used questionnaire. The variables studied were the principal managerial leadership $\left(\mathrm{X}_{1}\right)$, compensation $\left(\mathrm{X}_{2}\right)$ as independent variables and performance of science physics teachers $(\mathrm{Y})$ as dependent variable. Prior to use in the true research, the validity and reliability of these instrument was done. To reveal relationships between variables, correlation analysis was performed, while to know the effect of independent variables on the dependent variable regression analysis also performed. Analysis of the validity, reliability, correlation and regression analysis was performed using SPSS program version of 18.0 for windows. The results showed that between principal managerial leadership and teacher performance there is a very high correlation. Between compensation with the performance have high correlation and the combination of principals' managerial leadership and compensation with the performance there is a very high correlation. Regression analysis showed that the independent variables principals managerial leadership and compensation, or a combination of both contribute to or affect the performance of physical science teacher at senior high school in the district Baguala.
\end{abstract}

Keywords: physics education, teacher performance, leadership, Baguala

\section{Introduction}

Nowadays, many obstacles have faced by the government in improving the quality of learning and education. One of the obstacles to improve the quality of learning is inequity in the quality of teachers in schools. As well known, teachers are the main factor that determines the success of the learning process. The quality of teachers, both academic and non-academic, influences the quality of learning and education in general (Arifin, 2013).

In Maluku context, until now the quality of education has not shown significant improvement. Some reports of competency test placed Maluku in the lowest position. Teacher competency test results during the last five years have always put Maluku in the final rankings. The results of initial competency tests of teacher for certification in 2015 also showed that Maluku was placed in the final ranking of five provinces with a lower score (34.5) than the highest value of national score (50.1).

The low quality of teachers is basically an accumulation of many factors that affect the competence of teachers. Teacher performance is basically a part of teachers' competencies related to professional competence, pedagogical competence, social competence and personal competence. If these competences of teachers are low, teacher's performance will also be low (Arifin, 2015a).

Teacher performance was affected by many factors. According to Tambunan (2014) and Yani et al. (2015) factors that affected teachers performance consist of school leadership, teachers' interests, attitudes of teachers, teacher motivation, teacher's creativity, school culture, facility or infrastructure, job satisfaction, achievement motivation, and compensation. 
School leadership affects teacher performance. This can be very understandable, because the principal is a central figure in the school's management especially in quality improvement of the school. The school principal is the highest office of a school organization, and has a vital role in developing school as an institution (Fitriati et al., 2014). As stated by Abdullah et al. (2008) a very important role in school is the managerial ability of a principal.

Managerial leadership of a school principal is important and necessary to manage education in schools effectively and efficiently to achieve quality education expected by all parties. The school principal is the actual organization manager who did the strategies that have been decided to achieve educational goals. As a manager, the principal must have the ability to perform managerial functions concerning management activities such as planning, organizing, and controlling actuating (Tobin, 2014).

The principal managerial functions have been widely studied in the literature. In Indonesia, the function of school leadership as a manager was stipulated in the regulations of the Minister of National Education the Republic of Indonesia Number 13 in 2007. Under these laws, it is explained that managerial functions of the principal is school ranging from planning, development, utilization and empowerment of all elements in the school, including teachers, administration, students and infrastructure that exist in the schools to be used as possible to improve the quality of schools, teacher quality, and the quality of student. Principals managerial leadership will greatly affect the performance of teachers when supported with a great attention to the welfare of teachers. According to Sedarmayanti (2011), the theory of motivation implemented in pay incentive plans work is that the task given is always relates to the payment, and this affects the increase in employee productivity.

According to Jensen (2010) the level of performance is closely related to the workers' compensation system applied by the institution or organization they work. The compensation of improper influence increases one's performance. Inaccuracy of the compensation due to the provision of compensation was less attractive, nor is the award less precise does not make workers feel attracted to it. As a result, workers have no desire to improve their performance to get the compensation.

To improve the quality of the performance, it is necessary to adequately welfare level of compensation in the form of an essential right and a commitment to supported by the loyalty and the willingness of high employment and conducive of work climate as an school organization. One strategy used to improve the performance of teachers in school is the compensation program. With the award of compensation it is expected to improve the performance of teachers in teaching in schools. With compensation, school climate and commitment will improve performance or of peak performance (Saani, 2013). As stated by Sofo et al. (2012) the gap between attention of policy makers in the region and between schools leading a loss of management efficiency. This situation could affect the compensation is not right on time, so it can affect the performance of teachers.

It still reminds that teachers whose prosper economically tend to support their teaching job. Teachers do not bother thinking about family and financial needs. If all needs are met, teachers will focus on their duties, they will do anything to support and enrich their knowledge. With financially well-off, teachers also have the opportunity to continue their education to a higher level so that teachers will be more competent.

Physics is a subject that requires teachers with high competence and high performance. This is caused by learning physics requires deep exploration and purposed to make deep understanding in students.

Common reality encountered that when teachers teach physics, they do not teach in earnest. Sometimes physics teachers teach physics just to meet the modest achievement of the curriculum, regardless of whether students have understood the lesson they have taught.

Results of preliminary observations at the secondary school in the Baguala district have found that physics teachers as much as twenty five teachers have already obtained certification allowance. However, this allowance are not always right on time and other incentives are also irregular, and sometimes this condition affect the performance of teachers.

The compensation is not solely always associated with money, but with regard to the award or reward of achievement in the slightest form. But this is rarely obtained by the teacher and it is allegedly that this situation deals with school leadership. Therefore, the researchers want to conduct to reveal the impact of school leadership and compensation to the performance of physical science teachers in secondary schools in the district Baguala Ambon city. The purpose of this study was to determine the effect of managerial leadership principals on physics teacher's performance, to determine the effect of compensation to the physics teacher's performance, and to determine the effect of managerial leadership principals and compensation collectively to the performance of physics teacher at the senior high schools in district Baguala Ambon City. 


\section{Methodology}

\subsection{Site and Time}

This research was conducted in five secondary schools in District Baguala Ambon during first semester of 2015-2016 academic year.

\subsection{Population and Sample}

The population in this study is all Physics teacher in 5 secondary schools in districts Baguala as much as 25 teachers.

\subsection{Research Variable}

The variables in this study consisted of the independent variable, including Principal managerial leadership $\left(\mathrm{X}_{1}\right)$ and compensation $\left(\mathrm{X}_{2}\right)$, and the dependent variable, including physics teacher performance $(\mathrm{Y})$ (Figure 1).

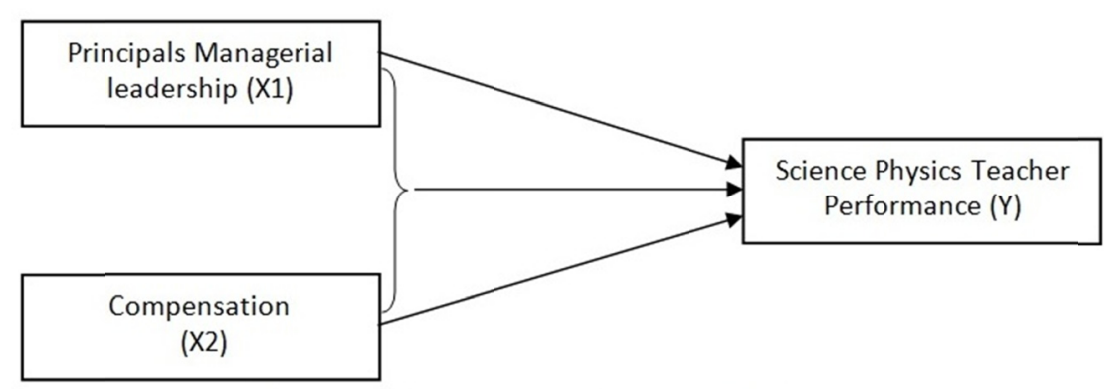

Figure 1. Frame work of research design

\subsection{Research Instruments}

The instrument used in this study is a questionnaire used to measure the performance of physics teacher in the secondary school in district Baguala Ambon City (Y), principals' managerial leadership $\left(\mathrm{X}_{1}\right)$, and compensation $\left(\mathrm{X}_{2}\right)$. Each statement will be answered by the respondents with five answer choices i,e: very satisfy (5), satisfy (4), sufficient (3), unsatisfy (2), and very unsatisfy (1).

\subsection{Research Procedure}

This study began with preparation of instrument for two independent variables and one dependent variable. Prior to use in the real research, the instrument was tested for its validity and reliability. The trial was conducted on 20 physics teacher as respondents in five schools. Test of the validity was based on the product moment correlation. If the product-moment correlation coefficient $>0.25$ the item is valid (Marguiriete et al., 2006). Reliability testing following the Cronbach alpha coefficient formula. If the value of Cronbach alpha coefficients $>0.70$ or $70 \%$, then the instrument is reliable (Hilton \& Brownlow, 2004; Lounsbury et al., 2006). After the test of validity and reliability was conducted, the valid and reliable instrument then use for really research for all twenty five science physics teacher.

\subsection{Data Analysis}

Data obtained from the results of questionnaire by 25 physics teacher was analyzed using descriptive quantitatively. To determine the relationship between $\mathrm{X}_{1}$ variables (Principal managerial leadership) with $\mathrm{Y}$ variable (teacher performance) and $\mathrm{X}_{2}$ (Compensation) with $\mathrm{Y}$ variable (the teacher performance) either alone or together was done with correlation analysis. The correlation between the variables $\mathrm{X}_{1}$ and $\mathrm{X}_{2}$ with $\mathrm{Y}$ was performed using bivariate correlation analysis or simple, whereas the correlation between $X_{1}, X_{2}$ and $Y$ together, was conducted by using multiple correlation analysis. Test criteria were used both bivariate correlation and multiple correlations as shown in Table 1 below: 
Table 1. Criteria for correlation result interpretation

\begin{tabular}{cc}
\hline Product-Moment Coefficient correlation & Criteria \\
\hline $0.00-0.199$ & Very low \\
$0.20-0.399$ & Low \\
$0.40-0.599$ & Medium \\
$0.60-0.799$ & High \\
$0.80-1.00$ & Very high \\
\hline
\end{tabular}

Creswell (2005).

Before correlation test was conducted, the normality of data was tested using Shapiro Wilk normality test (number of sample less than 30). To determine whether the correlation between the variables $X_{1}-Y, X_{2}-Y$ and $X_{1}$, $\mathrm{X}_{2}-\mathrm{Y}$ together linearly or not, the significance of the correlation coefficient also conducted. Between $\mathrm{X}_{1}$ and $\mathrm{X}_{2}$ to $\mathrm{Y}$ using $\mathrm{t}$ test, whereas among the variables $\mathrm{X}_{1}, \mathrm{X}_{2}-\mathrm{Y}$ together, used $\mathrm{F}$ test. Test criteria was required if the significance value $>0.05$ the correlation is not linear, or there is no influence of variables $\mathrm{X}_{1}$ or $\mathrm{X}_{2}$ to $\mathrm{Y}$. If $\operatorname{sig}<$ 0.05 the correlation is linear, or both $\mathrm{X}_{1}$ and $\mathrm{X}_{2}$ variables affect $\mathrm{Y}$. To know the contribution of variable $\mathrm{X}_{1}$ to $\mathrm{Y}$, $\mathrm{X}_{2}$ to $\mathrm{Y}$, and $\mathrm{X}_{1}, \mathrm{X}_{2}$ together to $\mathrm{Y}$ the regression analysis was performed. Analysis of the validity, reliability, correlation and regression was done with the assistance of computer program SPSS version 21.0 for Windows.

\section{Results and Discussion}

\subsection{Analysis of Questionnaire Data}

Questionnaire data is the result of the calculation of average respondents for all items of instruments on each variable. The average score of respondents was used in order to determine whether the average score of respondents fall into the category of very satisfy (5), satisfy (4), sufficient (3), unsatisfy (2) or very unsatisfy (1). The recapitulation of the average response of 25 respondents for the 35 item of variables $X_{1}, 29$ item for $\mathrm{X}_{2}$, and the 35 item for $Y$ variables are valid and used in the really research as shown in Figure 2.

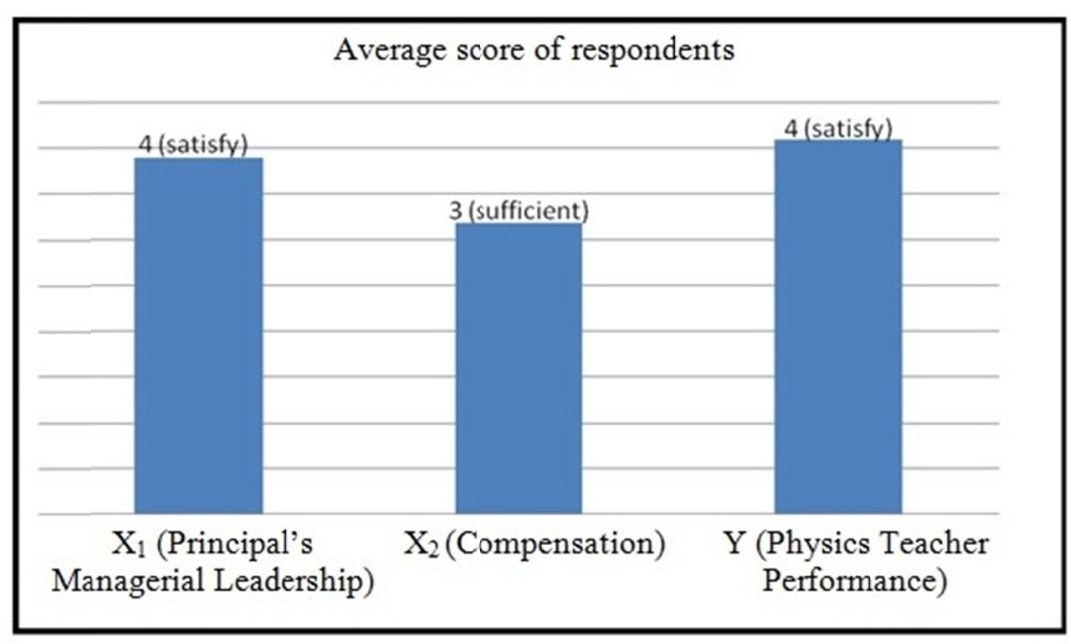

Figure 2. Average score of respondents for $\mathrm{X}_{1}, \mathrm{X}_{2}$ and $\mathrm{Y}$ variables

Data in Figure 2 shows that the variable of principal managerial leadership $\left(\mathrm{X}_{1}\right)$ and the quality of teaching and teachers $(\mathrm{Y})$ are in the satisfy category, while the variable compensation in the sufficient category.

\subsection{The Results of Validity and Reliability Test of Instrument}

Validity test is done to determine the validity of item. Invalid item is not used in this study. In contrast, valid instrument means that the statement could represent the topic which was studied. According to Weyner (2007), the validity of an instrument shows the ability of the instruments to measure precisely what it will be measured. Formerly, Diem (2002) was argued that in order to obtain a valid instrument in accordance with what it is 
supposed to be measured, it's necessary to test the validity. Based on validity test of items by using product moment correlation, and reliability using Cronbach Alpha coefficients, the obtained results as shown in Table 2.

Table 2. Validity and reliability of items from X1 (Principal managerial leadership)

\begin{tabular}{|c|c|c|c|c|c|c|}
\hline $\mathrm{X} 1$ variable & Number of items & $\begin{array}{c}\text { Pearson } \\
\text { coefficients } \\
\text { correlation }\end{array}$ & $\begin{array}{c}\text { Criteria of } \\
\text { validity }\end{array}$ & Information & $\begin{array}{c}\text { Cronbach Alpha } \\
\text { coefficients }\end{array}$ & Information \\
\hline & $\mathrm{X} 1 \_1$ & .572 & 0.25 & Valid & .940 & Reliable \\
\hline & $\mathrm{X} 1 \_2$ & .419 & 0.25 & Valid & .941 & Reliable \\
\hline & $\mathrm{X} 1 \_3$ & .543 & 0.25 & Valid & .940 & Reliable \\
\hline & $\mathrm{X} 1 \_4$ & .654 & 0.25 & Valid & .939 & Reliable \\
\hline & $\mathrm{X} 1 \_5$ & .587 & 0.25 & Valid & .939 & Reliable \\
\hline & X1_6 & .469 & 0.25 & Valid & .940 & Reliable \\
\hline & $\mathrm{X} 1 \_7$ & .813 & 0.25 & Valid & .937 & Reliable \\
\hline & $\mathrm{X} 1 \_8$ & .680 & 0.25 & Valid & .938 & Reliable \\
\hline & X1_9 & .504 & 0.25 & Valid & .940 & Reliable \\
\hline & $\mathrm{X} 1 \_10$ & .347 & 0.25 & Valid & .942 & Reliable \\
\hline & $\mathrm{X} 1 \_11$ & .473 & 0.25 & Valid & .940 & Reliable \\
\hline & $\mathrm{X} 1 \_12$ & .696 & 0.25 & Valid & .939 & Reliable \\
\hline & $\mathrm{X} 1 \_13$ & .463 & 0.25 & Valid & .940 & Reliable \\
\hline & $\mathrm{X} 1-14$ & .490 & 0.25 & Valid & .940 & Reliable \\
\hline & $\mathrm{X} 1-15$ & -.085 & 0.25 & Not valid & .931 & Reliable \\
\hline & $\mathrm{X} 1-16$ & .573 & 0.25 & Valid & .940 & Reliable \\
\hline & $\mathrm{X} 1 \_17$ & .437 & 0.25 & Valid & .941 & Reliable \\
\hline & $\mathrm{X} 1 \_18$ & .517 & 0.25 & Valid & .940 & Reliable \\
\hline Principal & X1_19 & .407 & 0.25 & Valid & .941 & Reliable \\
\hline Managerial & $\mathrm{X} 1 \_20$ & .046 & 0.25 & Not valid & .930 & Reliable \\
\hline \multirow[t]{19}{*}{ leadership } & $\mathrm{X} 1 \_21$ & .596 & 0.25 & Valid & .939 & Reliable \\
\hline & X1_22 & .656 & 0.25 & Valid & .939 & Reliable \\
\hline & $X 1 \_23$ & .523 & 0.25 & Valid & .940 & Reliable \\
\hline & X1_24 & .721 & 0.25 & Valid & .938 & Reliable \\
\hline & $\mathrm{X} 1 \_25$ & .565 & 0.25 & Valid & .939 & Reliable \\
\hline & $X 1 \_26$ & .627 & 0.25 & Valid & .939 & Reliable \\
\hline & $X 1 \_27$ & .394 & 0.25 & Valid & .941 & Reliable \\
\hline & X1_28 & .401 & 0.25 & Valid & .941 & Reliable \\
\hline & X1_29 & .463 & 0.25 & Valid & .940 & Reliable \\
\hline & $\mathrm{X} 1 \_30$ & .617 & 0.25 & Valid & .939 & Reliable \\
\hline & X1_31 & .615 & 0.25 & Valid & .939 & Reliable \\
\hline & $\mathrm{X} 1 \_32$ & .552 & 0.25 & Valid & .940 & Reliable \\
\hline & $X 1 \_33$ & .295 & 0.25 & Valid & .926 & Reliable \\
\hline & X1_34 & .507 & 0.25 & Valid & .940 & Reliable \\
\hline & X1_35 & .596 & 0.25 & Valid & .939 & Reliable \\
\hline & $\mathrm{X} 1 \_36$ & .566 & 0.25 & Valid & .939 & Reliable \\
\hline & X1_37 & .608 & 0.25 & Valid & .939 & Reliable \\
\hline & X1_38 & .064 & 0.25 & Not valid & .929 & Reliable \\
\hline & X1_39 & .728 & 0.25 & Valid & .938 & Reliable \\
\hline
\end{tabular}

Based on Table 2, it appears that on the 39 items of principal managerial leadership variable $\left(\mathrm{X}_{1}\right)$ there are 36 valid items and 4 items are not valid. This unvalid items then disposed of and not used in a real research. Reliability value for all 35 items for $X_{1}$ variable categorized as very high (Cronbach Alpha values $>90 \%$ ). These results indicate that the item of $X_{1}$ instrument is reliable. According to Gliem \& Gliem (2003) the Cronbach Alpha coefficients for reliability analysis range from $0-1$. The reliability is very high, if the value of Cronbach Alpha coefficients reach a minimum number $>0.90$ or more than $90 \%$.

Variable compensation $\left(\mathrm{X}_{2}\right)$ consists of 39 items. The validity test of these items show that 10 items not valid, 
and still remains 29 valid items and can be used for further research. As same as the $\mathrm{X}_{1}$ variable. The criteria for validity that used if the value of the Product-Moment correlation coefficient $>0.25$, while the reliability of items is categorized as very high (Cronbach's Alpha coefficient values $>90 \%$ ) (Table 3).

Table 3. Validity and reliability of $\mathrm{X}_{2}$ (Compensation)

\begin{tabular}{|c|c|c|c|c|c|c|}
\hline $\mathrm{X}_{2}$ Variable & $\begin{array}{l}\text { Number of } \\
\text { instrument }\end{array}$ & $\begin{array}{c}\text { Pearson } \\
\text { correlation } \\
\text { coefficient }\end{array}$ & $\begin{array}{c}\text { Criteria for } \\
\text { validity }\end{array}$ & Information & $\begin{array}{c}\text { Alpha Cronbach } \\
\text { coefficient }\end{array}$ & Reliability \\
\hline & $\mathrm{X} 2 \_1$ & .547 & 0.25 & Valid & .928 & Reliable \\
\hline & $\mathrm{X} 2 \_2$ & .352 & 0.25 & Valid & .930 & Reliable \\
\hline & $\mathrm{X} 2 \_3$ & .571 & 0.25 & Valid & .927 & Reliable \\
\hline & $\mathrm{X} 2 \_4$ & .671 & 0.25 & Valid & .926 & Reliable \\
\hline & $\mathrm{X} 2 \_5$ & .631 & 0.25 & Valid & .926 & Reliable \\
\hline & $\mathrm{X} 2 \_6$ & .544 & 0.25 & Valid & .927 & Reliable \\
\hline & $\mathrm{X} 2 \_7$ & .559 & 0.25 & Valid & .927 & Reliable \\
\hline & $\mathrm{X} 2 \_8$ & .666 & 0.25 & Valid & .926 & Reliable \\
\hline & X2_9 & .673 & 0.25 & Valid & .925 & Reliable \\
\hline & $\mathrm{X} 2 \_10$ & .473 & 0.25 & Valid & .928 & Reliable \\
\hline & $\mathrm{X} 2 \_11$ & .353 & 0.25 & Valid & .930 & Reliable \\
\hline & $\mathrm{X} 2 \_12$ & .739 & 0.25 & Valid & .926 & Reliable \\
\hline & $\mathrm{X} 2 \_13$ & .664 & 0.25 & Valid & .926 & Reliable \\
\hline & $\mathrm{X} 2 \_14$ & .594 & 0.25 & Valid & .927 & Reliable \\
\hline & $\mathrm{X} 2 \_15$ & .297 & 0.25 & Valid & .932 & Reliable \\
\hline & $\mathrm{X} 2 \_16$ & .520 & 0.25 & Valid & .928 & Reliable \\
\hline & $\mathrm{X} 2 \_17$ & .554 & 0.25 & Valid & .927 & Reliable \\
\hline & $\mathrm{X} 2 \_18$ & .606 & 0.25 & Valid & .926 & Reliable \\
\hline & X2_19 & .423 & 0.25 & Valid & .929 & Reliable \\
\hline \multirow[t]{20}{*}{ Compensation } & $X 2 \_20$ & .518 & 0.25 & 0,25 & .928 & Reliable \\
\hline & $X 2 \_21$ & .571 & 0.25 & 0,25 & .927 & Reliable \\
\hline & $X 2 \_22$ & .564 & 0.25 & 0,25 & .927 & Reliable \\
\hline & $X 2 \_23$ & .688 & 0.25 & 0,25 & .925 & Reliable \\
\hline & $X 2 \_24$ & .755 & 0.25 & 0,25 & .924 & Reliable \\
\hline & $X 2 \_25$ & .507 & 0.25 & 0,25 & .928 & Reliable \\
\hline & $X 2 \_26$ & .548 & 0.25 & 0,25 & .927 & Reliable \\
\hline & $X 2 \_27$ & .561 & 0.25 & 0,25 & .928 & Reliable \\
\hline & $\mathrm{X} 2 \_28$ & .461 & 0.25 & 0,25 & .928 & Reliable \\
\hline & X2_29 & .305 & 0.25 & 0,25 & .930 & Reliable \\
\hline & $\mathrm{X} 2 \_30$ & .021 & 0.25 & Not valid & .895 & Reliable \\
\hline & $X 2 \_31$ & -.036 & 0.25 & Not valid & .893 & Reliable \\
\hline & $X 2 \_32$ & .161 & 0.25 & Not valid & .892 & Reliable \\
\hline & $\mathrm{X} 2 \_33$ & .189 & 0.25 & Not valid & .893 & Reliable \\
\hline & $\mathrm{X} 2 \_34$ & .114 & 0.25 & Not valid & .894 & Reliable \\
\hline & $\mathrm{X} 2 \_35$ & -.037 & 0.25 & Not valid & .897 & Reliable \\
\hline & $\mathrm{X} 2 \_36$ & -.031 & 0.25 & Not valid & .897 & Reliable \\
\hline & $X 2 \_37$ & -.188 & 0.25 & Not valid & .898 & Reliable \\
\hline & $\mathrm{X} 2 \_38$ & .224 & 0.25 & Not valid & .892 & Reliable \\
\hline & X2_39 & .152 & 0.25 & Not valid & .893 & Reliable \\
\hline
\end{tabular}

Teacher performance variable $(\mathrm{Y})$ consists of 35 items. The validiy test result shows that all of 35 such items is valid and has high reliability (Cronbach's alpha coefficient values $>90 \%$ ) (Table 4). 
Table 4. Validity and reliability result of Y variable (physics teacher's performance)

\begin{tabular}{|c|c|c|c|c|c|c|}
\hline Y Variable & $\begin{array}{l}\text { Number of } \\
\text { items }\end{array}$ & $\begin{array}{c}\text { Pearson correlation } \\
\text { coefficient }\end{array}$ & Criteria & Information & $\begin{array}{c}\text { Cronbach Alpha } \\
\text { coefficients }\end{array}$ & Reliability \\
\hline \multirow{35}{*}{$\begin{array}{c}\text { Physics Teacher's } \\
\text { Performance }\end{array}$} & Y_1 & .795 & 0.25 & Valid & .969 & Reliable \\
\hline & Y_2 & .696 & 0.25 & Valid & .970 & Reliable \\
\hline & $\mathrm{Y} 33$ & .853 & 0.25 & Valid & .969 & Reliable \\
\hline & $Y_{-} 4$ & .806 & 0.25 & Valid & .969 & Reliable \\
\hline & Y_5 & .852 & 0.25 & Valid & .969 & Reliable \\
\hline & Y_6 & .905 & 0.25 & Valid & .969 & Reliable \\
\hline & Y_7 & .812 & 0.25 & Valid & .969 & Reliable \\
\hline & Y_8 & .827 & 0.25 & Valid & .969 & Reliable \\
\hline & Y_9 & .831 & 0.25 & Valid & .969 & Reliable \\
\hline & Y_10 & .770 & 0.25 & Valid & .969 & Reliable \\
\hline & Y_11 & .862 & 0.25 & Valid & .969 & Reliable \\
\hline & $Y_{-} 12$ & .916 & 0.25 & Valid & .969 & Reliable \\
\hline & Y_13 & .923 & 0.25 & Valid & .969 & Reliable \\
\hline & Y_14 & .827 & 0.25 & Valid & .969 & Reliable \\
\hline & Y_15 & .870 & 0.25 & Valid & .969 & Reliable \\
\hline & Y_16 & .887 & 0.25 & Valid & .969 & Reliable \\
\hline & Y_17 & .935 & 0.25 & Valid & .969 & Reliable \\
\hline & Y_18 & .933 & 0.25 & Valid & .969 & Reliable \\
\hline & Y_19 & .702 & 0.25 & Valid & .970 & Reliable \\
\hline & Y_20 & .792 & 0.25 & Valid & .969 & Reliable \\
\hline & Y_21 & .768 & 0.25 & Valid & .969 & Reliable \\
\hline & Y_22 & .838 & 0.25 & Valid & .969 & Reliable \\
\hline & Y_23 & .669 & 0.25 & Valid & .970 & Reliable \\
\hline & Y_24 & .667 & 0.25 & Valid & .970 & Reliable \\
\hline & Y_25 & .510 & 0.25 & Valid & .971 & Reliable \\
\hline & Y_26 & .265 & 0.25 & Valid & .973 & Reliable \\
\hline & Y_27 & .307 & 0.25 & Valid & .972 & Reliable \\
\hline & Y_28 & .495 & 0.25 & Valid & .971 & Reliable \\
\hline & Y_29 & .537 & 0.25 & Valid & .971 & Reliable \\
\hline & Y_30 & .278 & 0.25 & Valid & .972 & Reliable \\
\hline & Y_31 & .450 & 0.25 & Valid & .971 & Reliable \\
\hline & Y_32 & .395 & 0.25 & Valid & .971 & Reliable \\
\hline & Y_33 & .570 & 0.25 & Valid & .970 & Reliable \\
\hline & Y_34 & .643 & 0.25 & Valid & .970 & Reliable \\
\hline & Y_35 & .595 & 0.25 & Valid & .970 & Reliable \\
\hline
\end{tabular}

\subsection{Results of Normality Test}

Prior to correlation analysis the $\mathrm{X}_{1}, \mathrm{X}_{2}$, and $\mathrm{Y}$ variables were tested for its normality. The criteria for normality based on the significant value of Saphiro-Wilk at $\alpha 0.05$. If the significance value is more than 0.05 , the data is normal. Conversely, if the significance value $<0.05$, the data are not normally distributed. Results of data normality test showed that the data of the three variables $\mathrm{X}_{1}, \mathrm{X}_{2}$, and $\mathrm{Y}$ is normal (Table 5).

Tabel 5. Result of normality data of $\mathrm{X}_{1}, \mathrm{X}_{2}$, and $\mathrm{Y}$ variables

\begin{tabular}{lcc}
\hline Variables & Significance of Saphiro-Wilk & Information \\
\hline $\mathrm{X} 1$ & 0.218 & Normal \\
$\mathrm{X} 2$ & 0.637 & Normal \\
$\mathrm{Y}$ & 0.218 & Normal \\
\hline
\end{tabular}

\subsection{Results of Correlation Analysis}

To determine the relationship between variables $\mathrm{X}_{1}$ (principals managerial leadership) and $\mathrm{X}_{2}$ (Compensation) 
with a variable $\mathrm{Y}$ (the performance of physics teacher) partially or together, the correlation analysis was performed. The correlation between $\mathrm{X}_{1}$ with $\mathrm{Y}$ and $\mathrm{X}_{2}$ with $\mathrm{Y}$ variables performed using bivariate correlation analysis or simple correlation, whereas the correlation between $\mathrm{X}_{1}, \mathrm{X}_{2}$ and $\mathrm{Y}$ together, was conducted using multiple correlation analysis with the criteria as shown in Table 1, and the results was shown in Table 6 below:

Table 6. Correlation result of variables

\begin{tabular}{ccc}
\hline Correlation & Pearson coefficients correlation $(\mathrm{R})$ & Category \\
\hline $\mathrm{X} 1-\mathrm{Y}$ & 0.812 & Very high \\
$\mathrm{X} 2-\mathrm{Y}$ & 0.680 & High \\
$\mathrm{X} 1, \mathrm{X} 2-\mathrm{Y}$ & 0.848 & Very high \\
\hline
\end{tabular}

\subsection{The Results of Significance Test of Correlation Coefficient}

To determine whether the correlation between the variables $X_{1}-Y, X_{2}-Y$ and $X_{1}, X_{2}-Y$ together linearly or not, the significance of the correlation coefficient were tested. Among the variables $\mathrm{X}_{1}$ and $\mathrm{X}_{2}-\mathrm{Y}$ the significance of the correlation coefficient test using the $t$ test, whereas among the variables $X_{1}, X_{2}-Y$ together used $F$ test. Test criteria was required if the significance value $>0.05$ the correlation formed is not linear, or there is no influence of variables $\mathrm{X}_{1}$ or $\mathrm{X}_{2}$ to $\mathrm{Y}$. If $p<0.05$ the correlation is linear, or in other words, both $\mathrm{X}_{1}$ and $\mathrm{X}_{2}$ variables affect the $\mathrm{Y}$ variable. The results of significance test of the correlation coefficient between $\mathrm{X}_{1}$ with $\mathrm{Y}, \mathrm{X}_{2}$ with $\mathrm{Y}$, and $\mathrm{X}_{1}-\mathrm{X}_{2}$ with $\mathrm{Y}$ together (Table 7).

Table 7. Result of correlation coefficient significance test

\begin{tabular}{ccc}
\hline & Level of significance $(\alpha 0.05)$ & Information \\
\hline $\mathrm{X}_{1}-\mathrm{Y}$ & 0.000 & $\mathrm{Sig} /$ linier \\
$\mathrm{X}_{2}-\mathrm{Y}$ & 0.000 & $\mathrm{Sig} /$ linier \\
$\mathrm{X}_{1}, \mathrm{X}_{2}-\mathrm{Y}$ & 0.000 & $\mathrm{Sig} /$ linier \\
\hline
\end{tabular}

As seen in Table 7 the coefficient correlation between $\mathrm{X}_{1}$ with $\mathrm{Y}, \mathrm{X}_{2}$ with $\mathrm{Y}$, and $\mathrm{X}_{1}-\mathrm{X}_{2}$ with $\mathrm{Y}$ are linear or significant correlation, because the significance value $<0.005$.

\subsection{Regression Analysis}

Regression analysis was conducted in order to determine the contribution of independent variables on the dependent variable. In this case, the variable $\mathrm{X}_{1}$ to $\mathrm{Y}, \mathrm{X}_{2}$ to $\mathrm{Y}$, and for both $\mathrm{X}_{1}, \mathrm{X}_{2}$ to $\mathrm{Y}$ variable (Table 8).

Table 8. Result of regression analysis

\begin{tabular}{|c|c|c|c|c|c|}
\hline Variables & Regression models & $\begin{array}{c}\text { Correlation } \\
\text { coefficient }(\mathrm{R}) \\
\end{array}$ & $\begin{array}{l}\text { Determination } \\
\text { coefficient }\left(\mathrm{R}^{2}\right)\end{array}$ & $\begin{array}{c}\text { Level of } \\
\text { significance } \alpha 0.05\end{array}$ & Information \\
\hline $\mathrm{X}_{1}-\mathrm{Y}$ & $\mathrm{Y}=0.821+0.611 \mathrm{X}_{1}$ & 0.812 & $0.660(66 \%)$ & 0.000 & sig/linier \\
\hline $\mathrm{X}_{2}-\mathrm{Y}$ & $\mathrm{Y}=1.456+0.342 \mathrm{X}_{2}$ & 0.680 & $0.462(46.2 \%)$ & 0.000 & sig/linier \\
\hline$X_{1}, X_{2}-Y$ & $\mathrm{Y}=0.828+0.152 \mathrm{X}_{1}+0.475 \mathrm{X}_{2}$ & 0.848 & $0.719(71.9 \%)$ & 0.000 & sig/linier \\
\hline
\end{tabular}

Contributions of independent variables $\left(\mathrm{X}_{1}\right.$ and $\left.\mathrm{X}_{2}\right)$ to $\mathrm{Y}$, can be seen through the coefficient of determination $\left(\mathrm{R}^{2}\right)$. The data in Table 7 shows that the contribution of principals managerial leadership $\left(\mathrm{X}_{1}\right)$ variable to the variable physics teacher performance $(\mathrm{Y})$ is approximately $66 \%$, while the contribution of variable compensation $\left(\mathrm{X}_{2}\right)$ to the physics teacher performance $(\mathrm{Y})$ is about $46.2 \%$. Combined these two variables jointly contribute to variable $\mathrm{Y}$ as much as $71.9 \%$. These results indicate that both principals managerial leadership variable and compensation gave a major contribution to the performance of physics teachers performance in secondary schools districts in Baguala Ambon city.

\subsection{Discussion}

\subsubsection{Correlation between Principal Managerial Leadership with Physics Teacher Performance}

The results showed that the relationship between principals managerial leadership and physics teacher performance is very high $(\mathrm{r}=0.812)$ and the correlations are significant and linear. Results of regression analysis 
also showed that managerial leadership principals affect teacher performance with a contribution of $66 \%$. This result is associated with Figure 1 which shows that the principal managerial leadership is satisfy.

Principal or headmaster is the highest or top leader in a school organization. He has very important role in developing school-led institution. Managerial leadership is one of the seven core functions of the principal. The principal's role as manager was stipulated by the regulation of the Minister of National Education of the Republic of Indonesia Number 13 in 2007. This laws set out the duties and managerial roles principals which consists of planning the school organization and development according to the needs. In order to optimally empowering schools, management change and development of the school should be implemented to create effective learning, empowering optimally relationship between school and community in order to find fresh ideas, learning resources, and school funding, and the placement and capacity development of learners.

Managerial functions of headmasters as defined in these regulations is to manage the development of curriculum and learning activities in accordance with the direction and objectives of national education, financial management of the school in accordance with the accountable principle of management, transparent, and efficient, manage school administration in supporting the achievement of the objectives of the school, managing special service unit of school in supporting learning and activities of students in school, manage the information systems of school in support programs and decision-making, utilizing advances in information technology to improve learning and school management, monitoring, evaluation and reporting the implementation of school program, as well as follow-up plans.

The regulation stated that managerial skills of principals including: planning, organizing, mobilization and supervision. The ability to manage a process to determine and achieve the goals that have been set through the utilization of human resources and other sources. In other words, management is the process of managing an organization to be able to achieve its intended purpose. Thus, as a manager, the principal demanded to make the planning, organizing, directing and monitoring. With good managerial abilities expected every school principal is able to be advocates and enforcers of discipline for teachers so that they are able to show good performance productivity.

The performance of teachers in secondary schools in Baguala district is in satisfiy category. This shows that the principal already perform managerial functions properly. Perhaps, the principal has been able to do planning and good management of the potential possessed by the school such as planning for the improvement of the quality and competence of teachers in these schools. In addition, principals also been able to create a culture and climate of the school conducive and innovative to form a high motivation of the teachers which in turn have an impact on improving teacher performance. Arifin (2015b) stated that the school culture affects the performance of teachers. The quality teacher performance also influenced by school leadership, and capability of implementing the managerial function properly. School principals already have the ability to manage, striving for improvement and optimizing the procurement and utilization of school facilities and infrastructure to support the implementation of the learning process. Upon ability-with managerial skills possessed by the principal, is able to give a positive effect on teachers as an integral part of the school leadership, and this leading the positive performance shown through the quality of teaching and teacher satisfactory.

\subsubsection{Relationship between Compensation with Physics Teacher Performance}

The results showed that the compensation variable is linked to teacher performance variable, high categorized, and the quality of these relationships is significant and linear. Regression analysis showed that the contribution of compensation on teacher performance amounted to $46.2 \%$. This is associated with the data in Figure 1, and can be seen that compensation is sufficient categories, while the performance of teachers is satisfy. These results show that the compensation given to the physics teacher in the district Baguala are adequate, or in other words, the compensation awarded has fulfilled what is desired by the teacher, may also be compensated in accordance with what the teacher wants, so that the alleged provision of such compensation affect both the performance of teachers, and motivate teachers to improve their quality of teaching.

Sedarmayanti (2001) stated that compensation is a gift in form of fringe benefits both directly or indirectly like money, or things to employees as a reward due to their work. Dessler (2003) also stated that the compensation can be like a rewards not just in the form of money or non-financial (nonfinancial rewards) and can't be quantified with numbers, but more qualitative as praise, motivation, reward, attention, more challenging work, working hours flexible and more prestigious office. If the compensation in the form of salary or wages, benefits or incentives, the amount must be increased, accuracy in time of administration should also be considered.

It is recognized that teachers are the people who directly interact with students, and become critical factors in developing the school organization's goals. Therefore, the teacher performance should be improved, one of 
which is through the provision of compensation. Saani (2013) stated that when carrying out their duties, they always need attention, appreciated, and motivation to improve the quality and competence of themselves as well as get paid accordingly, and given facility adequate support and support activities of teaching, the teacher would have excited the work included in the learning process. Awarding monetary compensation for teachers in Indonesia is done through the provision of allowance teacher certification. Kanto et al. (2014) stated that there is a significant influence allowance teacher certification on work motivation of teacher and teacher job satisfaction. It is undeniable that the provision of compensation in the form of salary or wages, benefits, and incentives, will increase the motivation of teachers, and teachers will be eager to work and teach. Usman (2010) stated that a person's motivation is influenced by the intensity of his motives (in this case is money). In performing his duties as a teacher, of course earn money as their wage suite also is the desire of every teacher. If the wages earned appropriate, it will improve the welfare of teachers. Teachers prosperous will focus to continue to work, their performance will increase, and in turn will improve their quality and competence for the overall improvement of the learning quality.

\subsubsection{Correlation between Principals Managerial Leadership and Compensation with Physics Teacher} Performance

Correlation between managerial leadership of principals and compensation and science teacher performance is very high $(r=0.848)$ and the contributions of both on teacher performance amounted to $71.9 \%$. These results indicate that both managerial leadership of principal and compensation collectively affect science physics teacher performance. A teacher performance results achieved by teachers in carrying out the tasks assigned to him based on skill and determination as well as the use of time. The performance of teacher will be good if teacher can implement the required elements as a strong commitment to their task of teaching, master and develop learning materials, teaching discipline and creativity in implementing the teaching and other purposes. Commitment of the teachers in carrying out his duties as a teacher, needs to be balanced with the provision of adequate compensation. According to Jensen et al. (2010) the compensation is very important for teachers, because the amount of compensation is the acceptance or measure the value of a teacher's job itself. The size of the compensation can affect the performance of teachers. If the compensation that given was appropriately and correctly, teachers will gain satisfaction in their work, and can encourage them to show a good performance so that the purpose of education in a school can be met.

The achievement of educational goals in schools is also determined by the success of the principals in managing the teaching staff was available at the school. The school principal is one of the components that influence the improvement of teacher performance (Hallinger \& Hack, 2010). The school principal is responsible for the provision of education, school administration, coaching other education personnel and the efficient utilization and maintenance of facilities and infrastructure (Yasin, 2013). As the highest leader in the school, a school principal must have managerial capability and high commitment and flexibility in performing their duties. School leadership must be able to work on improving the performance of teachers through capacity-building program of education personnel (Leithwood et al., 2008)

If a leader do not ever pay attention to the needs of members for whom he leads, in this case just like observing the right time in salaries, job promotion, proposal reception allowances or incentives, never pay attention, rewards, and appreciate greatly work of teachers, this condition can leads teachers to feel neglected, ignored and unappreciated. This change will provide a not conducive work situation. Teachers will be refuse to work, lazy and. This will affect the performance of teachers. Conversely, if the managerial leadership principals were able to pay attention to the needs of teachers, this is allegedly can improve the quality and competence of teachers, provide supporting facilities, support and funding teachers to work, giving awards to teachers with great work, and strive to increase the allowances or incentives to teachers in both quantity and timeliness of administration, regard the teacher as a partner in charge, establish effective communication with the teacher, always listen and receive input from teachers and build democratic attitude, this will leading teacher to will feel appreciated. Teachers will feel that the task and the work were not wasted. Teachers will also be proud of themself, enthusiastic, and motivated to perform well and this can be addressed through good performance. Marks and Printy (2003) stated that in order to improve the quality of education in schools, there must be understanding and coordination between teachers and principals in the various aspects related to the creation of quality schooling.

Apparently, the principal in high school in Baguala District was able to apply managerial leadership satisfy category, and followed by giving adequate compensation to the performance of teachers in secondary schools in the Baguala district is satisfy category. This condition is good, and should be improved. Baguala district is one of the districts in the administrative area of Ambon city. This area is very close to the center of both provincial and city governments, so that the various changes that occur in connection with improving the quality of education 
can be quickly adopted and adapted to the school environment. Attention central and local governments through the allowance teacher certification and Ambon city administration to administration incentives to teachers, although not examined in this study, but it is thought to be one of the factors that influence the performance of teachers in the city of Ambon included in District Baguala.

\section{Conclusion}

Principals' managerial leadership and compensation positive correlate and significantly affected physics teacher performance in secondary school in Baguala Distric-Ambon City. Correlation between principals managerial leadership with physics teacher performance is very high, as well as principal managerial leadership and compensation, while between compensation and teacher performance, the correlation is high categorized. For both dependent variables i,e principals managerial leadership and compensation significantly affect the performance of physics teacher performance at the senior high school in Baguala District of Ambon

\section{References}

Abdullah, A. G., Huq, K. E., \& Ismail, A. (2008). Headmaster' Managerial Roles Under School-Based Management and School Improvement: A Study in Urban Secondary Schools of Bangladesh. Educationist II, 2, 63-73.

Arifin, H. M. (2013). The Influence of Competence and External Motivation Factors toward Teacher Working Performance in Jayapura-Papua Indonesia. IOSR Journal of Business and Management, 7(5), 1-7. https://doi.org/10.9790/487X-0750107

Arifin, H. M. (2015a). Effect of Competence and Motivation on Teacher Performance and Primary and Secondary Education Quality at Yapis Education in Jayapura-Indonesia. Australian Journal of Basic and Applied Sciences, 9(3), 630-637.

Arifin, H. M. (2015b). The Influence of Competence, Motivation, and Organisational Culture to High School Teacher Job Satisfaction and Performance. International Education Studies, 8(1), 38-45

Creswell, J. W. (2005). Educational Research: Planning,. Conducting, and Evaluating Quantitative and Qualitative. Research. Upper Saddle River, NJ.

Dessler, G. (2005). Human Resources Management (10th ed., p. 390). Prentice Hall.

Diem, K. G. (2002). A Step-by-Step Guide to Developing Effective Questionnaires and Survey Procedures for Program Evaluation \& Research. 2004 by Rutgers Cooperative Research \& Extension, NJAES, Rutgers, The State University of New Jersey.

Fitriyati, R., Romdana, R., \& Rosyidi, U. (2014). The Practice of the School Principal's Leadership in Sekolah Indonesia Kuala Lumpur (SIKL): The Study of Leadership Styles and Techniques with Cognitive Mapping Aproach. Procedia Social and Behavioral Sciences, $115, \quad 258-268$. https://doi.org/10.1016/j.sbspro.2014.02.434

Gliem, J. A., \& Gliem, R. R. (2003). Calculating, Interpreting, and Reporting Cronbach's Alpha Reliability Coefficient for Likert-Type Scales. Midwest Research to Practice Conference in Adult, Continuing, and Community Education, 82-88.

Hallinger, P., \& Heck, R. (2010). Leadership for Learning: Does Collaborative Leadership Make a Difference in School Improvement? Educational Management Administration and Leadership, 38(6), 654-678.

Hilton, P. R., \& Brownlow, C. (2004). SPSS Explained. East Sussex: Routledge.

Jensen, U., Yamashiro, G., \& Tibberts, K. (2010). What do we know about teacher pay for performance. Kamehameha School Research and Evaluation (pp. 2-20). Honolulu.

Kanto, Kulasse, Ahmad, M. A., Talib, S. B., \& Tiro, M. A. (2014). The Influence of Certification toward Work Motivation, Job Satisfaction, and Performance of State High Schools Guidance and Counseling Teacher in South Sulawesi. International Journal of Scientific and Technology Research, 3(8), 386-394.

Leithwood, K., Harris, A., \& Hopkins, D. (2008). Seven Strong Claims About Successful School Leadership. School Leadership and Management, 28(1), 27-42. https://doi.org/10.1080/13632430701800060

Lounsbury, J. W., Gibson, L. W., Richard, A., \& Saudargas, R. A. (2006). Scale Development. In F. T. L. Leong, \& J. T. Austin (Eds., p. 144), The Psychology Research Handbook: A Guide for Graduate Students and Research Assistants. Thousand Oaks: Sage Publications, Inc..

Marguerite, G. L., Spaulding, D. T., \& Voegtle, K. H. (2006). Methods in Educational Research: From Theory to 
Practice. San Fransisco: John Wiley \& Sons, Inc.

Marks, H., \& Printy, S. (2003). Principal Leadership and School Performance: An Integration of Transformational and Instructional Leadership. Education Administration Quarterly, 39(3), 370-397. https://doi.org/10.1177/0013161X03253412

Saani, A. J. (2013). Influence of Compensation and Supervision on Private Basic School Teachers Work Performance in Ashaiman Municipality. International Journal of Business and Social Science, 4(17), 64-69.

Sedarmayanti. (2001). Sumber Daya Manusia dan Produktivitas Kerja. Mandar Maju, Bandung.

Sofo, F., Fitzgerald, R., \& Jawas, U. (2012). Instructional Leadership in Indonesian School Reform: Overcoming the Problems to move forward. School Leadership \& Management, 35(5), 503-522. https://doi.org/10.1080/13632434.2012.723616

Tobin, J. (2014). Management and Leadership Issues for School Building Leaders. NCPEA Inernational Journal of Educational Leadership Preparation, 99(1), 1-14.

Weyner, J. (2007). Measurement: Reliability and Validity Measures. Johns Hopkins University

Yani, A., Rianita, L., \& Utami, R. (2015). Teachers; Professionalism and Its Affecting Factors: a Review on EFL Teachers; Perceptions in Indonesia. International Journal of Languange Learning and Applied Linguistics World, 8(40), 1-14.

Yasin, M., Mustamin., \& Tahir, L. M. (2013). Principal Leadership and the Achievement of National Education Standard in Indonesia. International Journal of Humanities and Social Science Invention, 2(8), 31-36.

\section{Copyrights}

Copyright for this article is retained by the author(s), with first publication rights granted to the journal.

This is an open-access article distributed under the terms and conditions of the Creative Commons Attribution license (http://creativecommons.org/licenses/by/4.0/). 